\title{
Comparative studies on mycosporine-like amino acids, paralytic shellfish toxins and pigment profiles of the toxic dinoflagellates Alexandrium tamarense, A. catenella and A. minutum
}

\author{
Jose I. Carreto*, Mario O. Carignan, Nora G. Montoya \\ Instituto Nacional de Investigación y Desarrollo Pesquero (INIDEP), Paseo Victoria Ocampo 1, PO Box 175, \\ 7600 Mar del Plata, Argentina
}

\begin{abstract}
Surface bloom-forming species, predominantly of the Dinophyceae, have the capacity to accumulate high amounts of mycosporine-like amino acids (MAAs). The 3 dinoflagellate species (Gonyaulacales, Dinophyceae), Alexandrium tamarense (Lebour) Balech, A. catenella (Weedon et Kofoid) Balech, and A. minutum Halim, are bloom-forming toxic isolates. They are usually found forming blooms near the surface, hence, they are exposed to high light conditions. Using an improved HPLC methodology, 9 MAAs were separated and identified. Several forms of atypical MAAs, not previously reported in the literature, were also revealed. The chromatographic behaviour of these new compounds, UV spectra, chemical properties and mass spectra indicate that they contain 2 or more common MAAs linked among themselves. These atypical MAAs were present in the 3 Alexandrium species. At the same time, the chromatographic profile of A. minutum, A. tamarense and A. catenella showed great differences. The biochemical composition of the cells is highly variable with growth conditions. Hence, we also reported, for the sake of a comparative discussion, the toxin and pigment composition of these Alexandrium isolates. The 3 species showed the same pigment pattern characteristic of peridinin-containing dinoflagellates. On the contrary, as reported previously, great variation of the toxin profiles was observed among the Alexandrium species. We conclude that, although MAAs are common among phytoplankton, the occurrence of different types of novel MAAs in the 3 Alexandrium species studied here would indicate some degree of biogeographic or ecotypic diversification.
\end{abstract}

KEY WORDS: Ultraviolet radiation - Mycosporine-like amino acids · Toxins · Photosynthetic pigments $\cdot$ Bloom-forming species $\cdot$ Alexandrium

\section{INTRODUCTION}

Mycosporines and mycosporine-like amino acids (MAAs) are amino acids or reduced amino acid derivatives of 2 cyclic units, an aminocyclohexenone (Mycosporines) and an aminocyclohexenimide (MAA), having absorption maxima in the 310 to $360 \mathrm{~nm}$ ultraviolet region. Mycosporines appear widespread among the fungi whereas MAAs have now been iso-

*E-mail: jcarreto@inidep.edu.ar lated from a broad array of marine species, ranging from a marine heterotrophic bacterium, cyanobacteria, eukaryotic algae, marine invertebrates, fish and a variety of other marine organisms (Bandaranayake 1998, Sinha et al. 1998). These compounds are biosynthesised via the shikimate pathway (Favre-Bonvin et al. 1976). Thus, only bacteria and algae can synthesise MAAs; other marine organisms acquire and metabolise these compounds by trophic transference, symbiotic or bacterial association (Bandaranayake 1998). Several hypotheses about the role of MAAs in biological systems have been formulated: (a) they may protect 
the cells from UV photodamage by playing a sunscreen role (Yentsch \& Yentsch 1982, Carreto et al. 1989, Neale et al. 1998); (b) they may act as antioxidants to prevent cellular damage resulting from UV-induced production of toxic oxygen species (Dunlap \& Yamamoto 1995); (c) they may act as transducer of UV wavelengths to wavelengths utilisable for photosynthesis (Sinha et al. 1998); (d) they may contribute to osmotic regulation (Oren 1997); and, (e) they may act as regulatory metabolites of sporulation (Arpin \& Bouillant 1981). However, experimental evidence indicates that the 2 major functions of MAAs are to act as photoprotective UV filters (Neale et al. 1998) or to exercise a regulatory effect on sporulation (Arpin \& Bouillant 1981).

High concentrations of these UV-absorbing compounds have been observed in several species of bloom forming dinoflagellates which accumulate in surface waters exposed to high light conditions (Yentsch \& Yentsch 1982, Boalch \& Haxo 1984, Carreto et al. 1989, Vernet et al. 1989, Jeffrey et al. 1999). The capacity to produce high amounts of MAAs confers on these species a competitive advantage to grow at high light intensity and short wavelengths. These conditions seem to prevail during the early development of near surface blooms. However, only a few dinoflagellate species have been analysed to date (Carreto et al. 1990b, Banaszak \& Trench 1995, Lesser 1996, Vernet \& Whitehead 1996, Neale et al. 1998, Jeffrey et al. 1999).

The 3 dinoflagellate species studied here, Alexandrium tamarense, A. catenella, and A. minutum, are bloom-forming toxic isolates; they produce high amounts of MAAs, saxitoxin and its derivatives, neurotoxins responsible for paralytic shellfish poisoning. In this paper, we report the MAA composition of these species using an improved HPLC method that allows the identification of previously reported compounds and revealed the presence of a new type of complex MAA. The toxin and pigment composition are highly variable between different clones of the same species isolated from different regions. Furthermore, the biochemical composition of cells varies with growth conditions (Anderson 1990, Oshima et al. 1990, Jeffrey et al. 1997). To take into account these variations, we also report the pigment and toxin composition of the Alexandrium isolates.

\section{MATERIALS AND METHODS}

Strains and culture conditions. Alexandrium tamarense (Lebour) Balech clone MDQ1096 isolated from Mar del Plata coast (Argentina), A. catenella (Weedon and Kofoid) Balech clone CC08 isolated from the XI Region of Chile, and A. minutum Halim 1960 clone
AL2V isolated from Ría de Vigo (Spain) were used in this study. Cultures were maintained at $12^{\circ} \mathrm{C}$ in L1 medium without silicon addition (Guillard 1995). Mar del Plata coastal water $(0.2 \mu \mathrm{m}$ filtered) was used as the medium base. Before the experiments, cultures were allowed to adapt to experimental conditions for several weeks at an irradiance of $65 \pm 5 \mu \mathrm{mol}$ quanta $\mathrm{m}^{-2} \mathrm{~s}^{-1}$ photosynthetically active radiation (PAR), provided by 'cool-white' fluorescent bulbs on a 14:10 h light:dark cycle. Scalar irradiance ( $\left.E_{0}, P A R\right)$ was measured inside the flasks by means of a QSL-100 quantum sensor (Biospherical Instruments). Cultures were harvested at late exponential growth phase, 4 to $6 \mathrm{~h}$ into the daily light cycle.

Pigment analysis. Subsamples were concentrated on Whatman GF/F filters. Pigments were extracted from the filters with $100 \%$ methanol and sonicated (Vibra Cell TM, Sonic and Materials Inc., Danbury, CT) at $0^{\circ} \mathrm{C}$. Extracts were filtered through GF/F filters to remove cells and debris. To avoid chromatographic artefacts, $20 \%$ water was added (Jeffrey et al. 1997) prior to injection. Aliquots of sample solution were automatically injected into a high-pressure gradient system HPLC (Shimadzu LC 10 A). For pigment elution we used the method described by Garrido \& Zapata (1997) with slight modification. The column was a Vydac 201 TP 54, $250 \times 4.6 \mathrm{~mm}$ i.d, protected with an Opti-Guard ${ }^{\mathrm{TM}} \mathrm{C} 18$ $(1 \mathrm{~mm})$ guard column. Mixing chamber and column were thermostated at $27^{\circ} \mathrm{C}$ by means of a CTO-10 AC (Shimadzu) column oven. Eluent A was a 45:35:20 mixture of methanol, acetonitrile and aqueous solution (0.25 M pyridine, $\mathrm{pH}$ adjusted to 5.3 with acetic acid), and Eluent $\mathrm{B}$ was always acetone. We adjusted the $\mathrm{pH}$ of Solvent A to 5.3 to obtain a better resolution of dinoxanthin from chlorophyll $c_{2}$. Peak detection was carried out using a model SPD-M10Avp diode array detector and a FR-10Axl spectrofluorometer (Shimadzu).

Pigments were identified by on-line diode array spectra and by co-chromatography with authentic standards purchased from VKI (The International Agency for ${ }^{14} \mathrm{C}$ determination, Denmark) or isolated and purified from cultures of Alexandrium tamarense. Calibration of the HPLC system was carried out using calibrated authentic standards from VKI or the extinction coefficients reported by Jeffrey et al. (1997) for prepared pigment standards.

Toxin analysis. Subsamples were concentrated on Whatman GF/F filters and extracted with acetic acid $0.5 \mathrm{M}$, sonicated and filtered, as described for pigments, and stored at $-20^{\circ} \mathrm{C}$ before analysis. The extracts were analysed by the post-column derivatization HPLC method of Oshima et al. (1989) slightly modified (Oshima 1995) using an Inertsil C8, 5 um analytical column $(4.6 \times 150 \mathrm{~mm})$, protected with an OptiGuard $^{\text {TM }}$ C8 $(1 \mathrm{~mm})$ guard column. An HPLC (previ- 
ously described), coupled with a double head reaction pump (Eldex AA 100-S-2) for delivering both oxidizing and acid reagents, and $10 \mathrm{~m}$ Teflon ${ }^{\mathrm{TM}}$ tubing $(0.25 \mathrm{~mm}$ i.d.) coiled to an aluminium block dry oven (Eppendorf FH-40) were used. Toxin calibrated standards were kindly donated by Dr Y. Oshima (Tohoku University, Sendai, Japan). The following abbreviations of toxins are used: $\mathrm{C} 1-\mathrm{C} 4=$ sulfocarbamoylsaxitoxins $1-4$; STX = saxitoxin $;$ neoSTX = neosaxitoxin; GTX1-GTX6 = gonyautoxins $1-6$; dcSTX = decarbamoylsaxitoxins; dcGTX3 = decarbamoylgonyautoxin 3 .

MAA analysis. Subsamples were filtered onto Whatman GF/F filters and frozen $\left(-20^{\circ} \mathrm{C}\right)$ until analysis. MAAs were extracted with $100 \%$ HPLC grade methanol and sonicated. The extracts were filtered (Whatman GF/F) and evaporated to dryness using a centrifugal vacuum evaporator (Centrivap, Labconco, Co.). The residue was redissolved in water and vortexed. After passing through a $100 \mathrm{k}$ Daltons ultrafilter (Ultraspin $^{\mathrm{TM}}$ ), samples were analysed by HPLC (previously described) as follows: individual MAAs were separated by reverse phase, gradient elution on Alltima (Alltech) $\mathrm{C} 18,5 \mu \mathrm{m}$ columns $(4.6 \mathrm{~mm}$ i.d. $\times 150 \mathrm{~mm}$ length) protected with an Alltech guard column cartridge ( $4.6 \mathrm{~mm}$ i.d. $\times 20 \mathrm{~mm}$ length) filled with the same material. They were connected in series and thermostated at $30^{\circ} \mathrm{C}$. An initial isocratic hold until $8 \mathrm{~min}$ with 0.2 acetic acid (Solvent A) was followed by a gradient (Table 1) with Solvent B (methanol:acetonitrile: $0.2 \%$ acetic acid, 25:25:50) at a flow rate of $1.0 \mathrm{ml}$ $\mathrm{min}^{-1}$. Peak detection was carried out using a diode array detector. Individual peaks were identified by online absorption spectra, retention time and cochromatography with prepared standards from the red algae Porphyra sp. (shinorine and porphyra-334; Takano et al. 1979), Porphyra tenera 'nori' (palythine and asterine) and Palmaria decipiens (palythinol and usujirene; Karentz et al. 1991), and from massive cultures of the dinoflagellate Alexandrium tamarense (mycosporine-glycine, palythenic acid and palythene). The isolation of standards were carried out by column chromatography on C18 (Alltech) and Dowex 50W $8 \mathrm{H}^{+}$form (100 to $200 \mathrm{mesh}$ ), followed by semipreparative HPLC fractionation (Econosil C18). Final purification was accomplished using the above-mentioned analytical method. Chemical identities of prepared standards were confirmed by alkaline hydrolysis and analysis of their amino acid composition by the method of Einarsson et al. (1986). Palythenic acid, palythene and usujirene were also chemically characterised by the method outlined by Carreto et al. (1990b), and their identity confirmed by electrospray mass spectrometry. Palythine-serine, mycosporine-methylamine:serine and myco-sporine-methylamine:treonine from the coral Pocillopora eydouxi, were kindly donated by Dr T. Teai
Table 1. Analytical HPLC gradient protocol for MAA separation. Eluent A: $0.2 \%$ acetic acid; Eluent B: methanol:acetonitrile: $0.2 \%$ acetic acid; 25:25:50. Flow rate: $1 \mathrm{ml} \mathrm{min}^{-1}$

\begin{tabular}{|lcc|}
\hline Time $(\min )$ & \% Eluent A & \% Eluent B \\
\hline 0 & 100 & 0 \\
8 & 100 & 0 \\
14 & 93 & 7 \\
25 & 90 & 10 \\
32 & 80 & 20 \\
40 & 75 & 25 \\
45 & 0 & 100 \\
50 & 0 & 100 \\
\hline
\end{tabular}

(Laboratoire de Biologie du stress en Milieu Marin, Papeete, Tahiti, French Polynesia). The concentrations of MAAs were quantified using the molar extinction coefficients $(\varepsilon)$ at the wavelengths of maximum absorption reported by Bandaranayake (1998). At the level of $80 \mathrm{ng}$ injected, the standard deviation $(\mathrm{n}=10)$ for porphyra-334 and shinorine is $\pm 0.4 \mathrm{ng}$. Retention time reproducibility for these MAAs is $\pm 0.01 \mathrm{~min}$. The abundance of new MAAs (M-333, M-320, M-335/360 and M-328/360) was calculated approximately using the calibration coefficients obtained for their MAA components. For other unknown MAAs the calibration coefficient of M-328/360 was used.

Isolation and partial characterisation of novel MAAs. Novel compounds were isolated from Alexandrium minutum by HPLC and characterised by their UV-absorption spectra, acid hydrolysis with $0.1 \mathrm{~N} \mathrm{HCl}$ at $50^{\circ} \mathrm{C}$ for $10 \mathrm{~min}$ and analysis of their MAAs composition as previously described. Some of these compounds were also characterised by electrospray mass spectrometry. Mass spectrometry was performed using a Hewlett Packard 1100 series LC/MSD system equipped with an orthogonal electrospray ionization (API-ES) interface. Compounds previously purified by HPLC were analysed by automatic flow injection analysis (FIA) using a fully integrated Hewlett Packard 1100 series HPLC/MSD equipped with variable volume autosampler. The fragmentor voltage was selected at $60 \mathrm{~V}$. Positive and negative-ion scanning were performed from 150 to $750 \mathrm{~m} / \mathrm{z}$.

\section{RESULTS}

\section{MAA composition}

HPLC separation of the extracts of Alexandrium species indicated the presence of several MAAs in quantifiable amounts (Fig. 1). Nine specific MAAs previously observed in marine organisms were identified. In the 3 species analysed, palythene was the predominant MAA, 

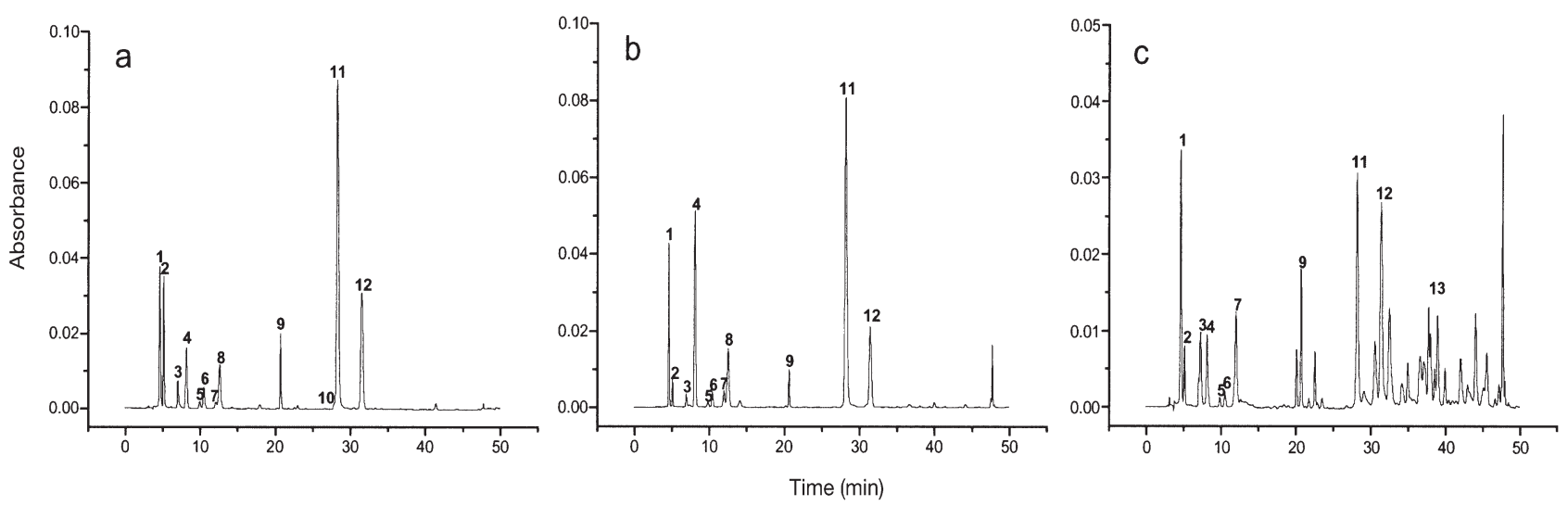

Fig. 1. HPLC chromatograms of MAA extracts (absorption at $330 \mathrm{~nm}$ ) from (a) Alexandrium catenella, (b) A. tamarense and (c) A. minutum. Peak identification: $1=$ shinorine, $2=$ palythine, $3=$ palythine-serine, $4=$ porphyra- $334,5=$ palythinol, $6=$ mycosporine-glycine, $7=\mathrm{M}-333,8=$ palythenic acid, $9=\mathrm{M}-320,10=$ usujirene, $11=$ palythene, $12=\mathrm{M}-335 / 360,13=\mathrm{M}-328 / 360$

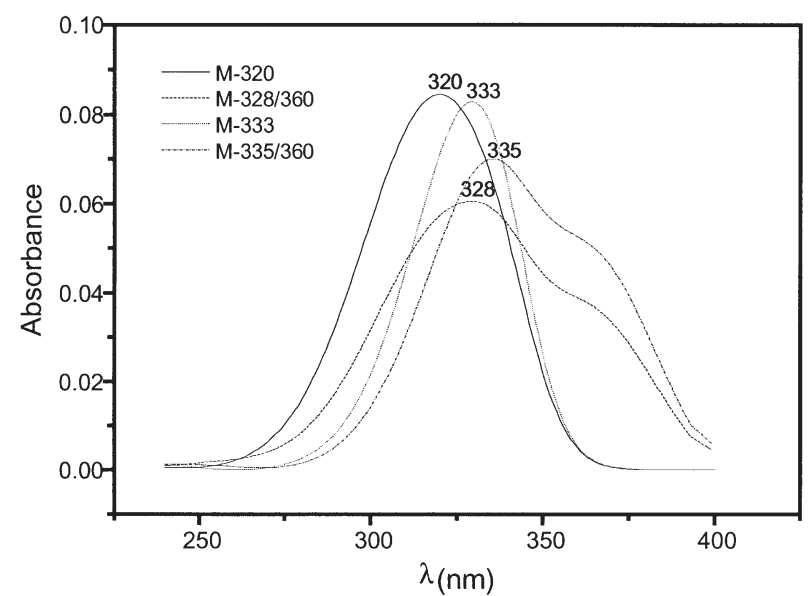

Fig. 2. Diode array spectra in HPLC eluent of the MAAs M-333, M-320, M-335/360 and M-328/360

Table 2. MAA content per cell and MAA percent ratios in Alexandrium species

\begin{tabular}{|c|c|c|c|c|c|c|}
\hline & \multicolumn{2}{|c|}{ A. catenella } & \multicolumn{2}{|c|}{ A. tamarense } & \multicolumn{2}{|c|}{ A. minutum } \\
\hline & pg cell ${ }^{-1}$ & $\%$ & pg cell ${ }^{-1}$ & $\%$ & pg cell ${ }^{-1}$ & $\%$ \\
\hline Shinorine & 0.70 & 7.6 & 0.44 & 7.2 & 0.53 & 5.6 \\
\hline Palythine & 0.69 & 7.5 & 0.09 & 1.5 & 0.12 & 1.3 \\
\hline Myc-methylamine-serine & 0.12 & 1.3 & 0.04 & 0.6 & 0.19 & 2.0 \\
\hline Porphyra-334 & 0.39 & 4.2 & 0.82 & 13.2 & 0.19 & 2.0 \\
\hline Palythinol & 0.04 & 0.4 & 0.02 & 0.3 & 0.02 & 0.2 \\
\hline Mycosporine-glycine & 0.81 & 8.8 & 0.35 & 5.7 & 0.23 & 2.4 \\
\hline M-333 & 0.04 & 0.5 & 0.08 & 1.4 & 0.30 & 3.1 \\
\hline Palythenic acid & 0.51 & 5.6 & 0.45 & 7.4 & - & - \\
\hline M-320 & 0.46 & 5.1 & 0.17 & 2.7 & 0.34 & 3.6 \\
\hline Usujirene & 0.05 & 0.5 & Traces & Traces & Traces & Traces \\
\hline Palythene & 4.01 & 43.9 & 2.82 & 45.6 & 1.09 & 11.6 \\
\hline M-335/360 & 1.21 & 13.3 & 0.59 & 9.5 & 0.86 & 9.1 \\
\hline M-328/360 & - & - & - & - & 0.26 & 2.8 \\
\hline Other MAAs & 0.12 & 1.0 & 0.31 & 5.0 & 5.30 & 56.8 \\
\hline
\end{tabular}

followed by palythine, mycosporine-glycine, porphyra334 and palythenic acid. Palythinol and usujirene were the minor components (Table 2). On occasions asterine was present in trace amounts. In addition to these known MAAs, the method allowed the detection of a series of complex-MAAs not previously reported in the literature. On-line diode array spectra showed a variety of compounds with atypical absorption spectra, characterised by the presence of 2 absorption maxima or pronounced shoulders in the UV region. In addition to these, the less polar compound in our chromatograms (Fig. 1) displayed an absorption spectrum similar to that of palythene. Some of these spectra are shown in Fig. 2. Although these type of compounds are present in the 3 Alexandrium isolates, the chromatographic profile of A. minutum showed the highest diversity and abundance of these novel MAAs (Fig. 1). Several compounds containing 2 MAAs with absorption maxima at 312 and $335 \mathrm{~nm}$ respectively, have been previously isolated from the cosmopolitan terrestrial cyanobacterium Nostoc commune (Böhm et al. 1995). In contrast to the $N$. commune compounds, the unknown MAAs detected in Alexandrium are very unstable in acidic media and they get decomposed during purification by ion exchange chromatography on Dowex-50W $8 \mathrm{H}^{+}$form. Treatment of water extract of $A$. minutum with $0.1 \mathrm{~N}$ $\mathrm{HCl}$ at $50^{\circ} \mathrm{C}$ for $10 \mathrm{~min}$ hydrolysed these compounds with the concomitant increase in the amount of some identified MAAs (shinorine, mycosporine-glycine, palythene and palythine).

Four of these novel MAAs, named provisionally as M-333, M-320, M-335/360 


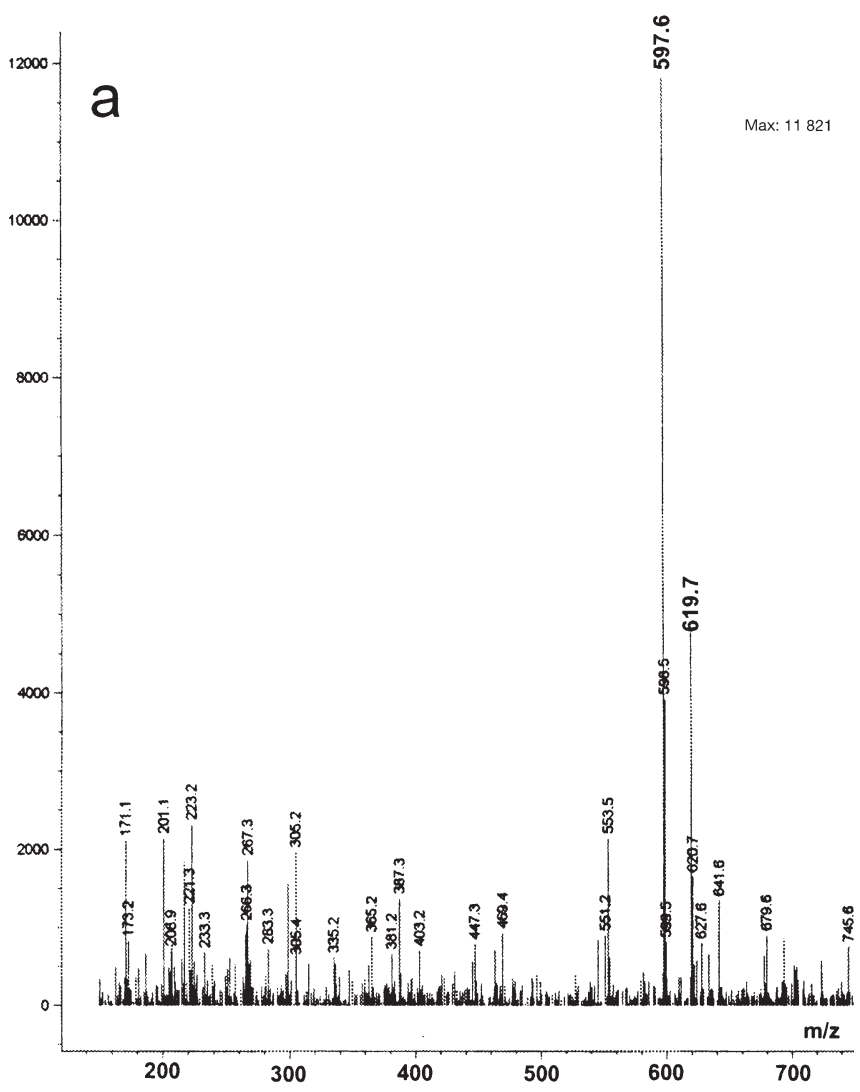

Fig. 3. ESI-mass spectra of the novel MAAs. (a) Negative ion mass spectrum of M-335/360. (b) Positive ion mass spectrum of M-333. (c) Negative ion mass spectrum of M-320

and M-328/360 were isolated by reverse phase HPLC and partially characterised. M-333 showed a typical symmetrical MAA spectrum centred, like shinorine, at $333 \mathrm{~nm}$ (Fig. 2). However, M-333 was less polar than shinorine (Fig. 1). Hydrolysis of M-333 with $0.1 \mathrm{~N} \mathrm{HCl}$ at $50^{\circ} \mathrm{C}$ for $10 \mathrm{~min}$ yielded shinorine. The positive-ion mass spectrum of M-333 (Fig. 3b) was characterised by an abundant protonated molecule $[\mathrm{M}+\mathrm{H}]^{+}$at $\mathrm{m} / \mathrm{z} 347.3$ with no significant fragmentation. The identity of the molecular ion was confirmed by the presence of a peak 23 mass units higher, attributed to the sodium cationized adduct. M-333 also exhibited an abundant $[\mathrm{M}-\mathrm{H}]^{-}$ (m/z 345.3) in negative ionization. The molecular mass of this compound (346.3) was 14 units higher than that of shinorine (332.3), the product of its acid hydrolysis. These results, together with the polarity and spectral properties of M-333, support the hypothesis that this MAA is a monomethyl ester of shinorine.

The spectrum of M-320 showed an asymmetric shape with maximum absorption at $320 \mathrm{~nm}$ (Fig. 2). This spectrum was similar to the combined molar spectra of shinorine plus mycosporine-glycine. Controlled acid hydrolysis yielded shinorine and mycosporineglycine in a molar ratio close to 1 (1.0:0.92). M-320
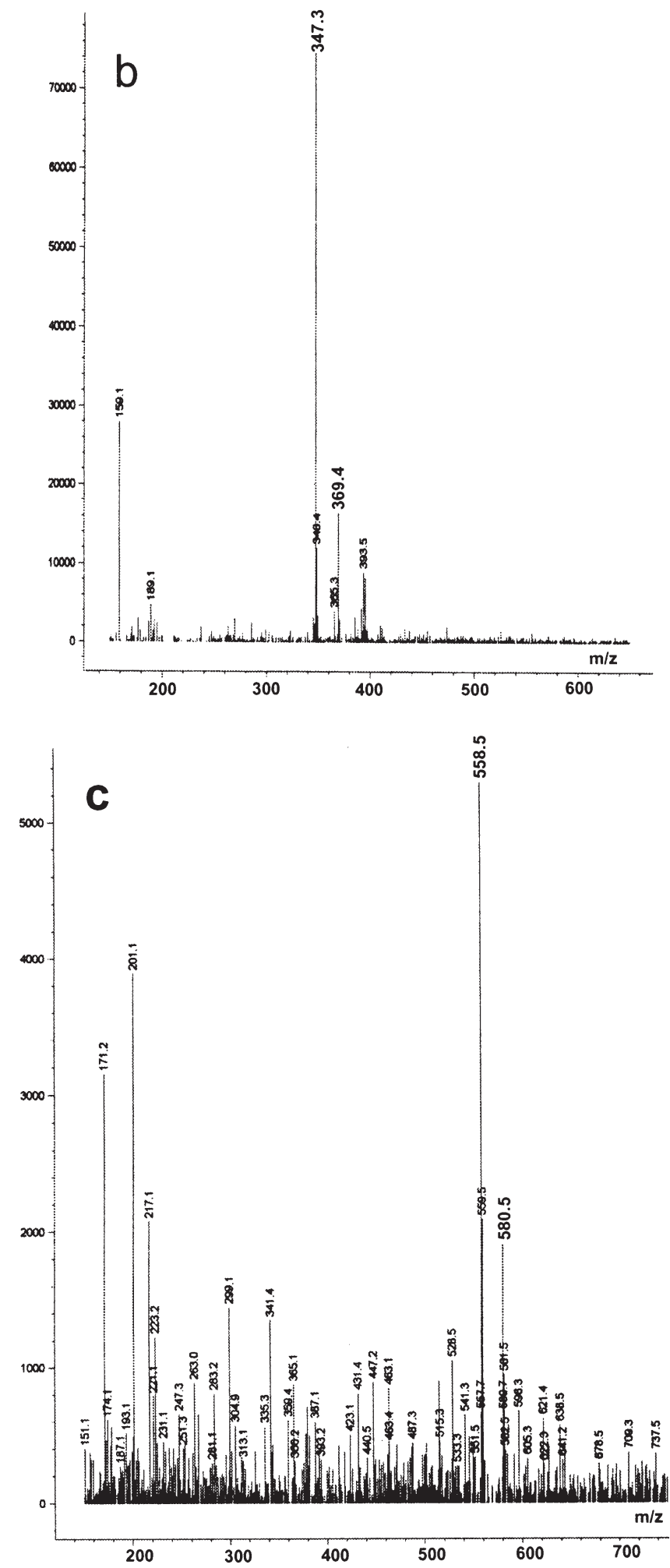

exhibited an abundant $[\mathrm{M}-\mathrm{H}]^{-}$ion $(\mathrm{m} / \mathrm{z} 558.5)$ in negative ionization (Fig. 3c) and an $[\mathrm{M}+\mathrm{H}]^{+}$ion (m/z 560.6) in positive ionization. The molecular mass of this compound was 18 units lower than the calculated mass addition of shinorine and mycosporine-glycine (m 577.5), 

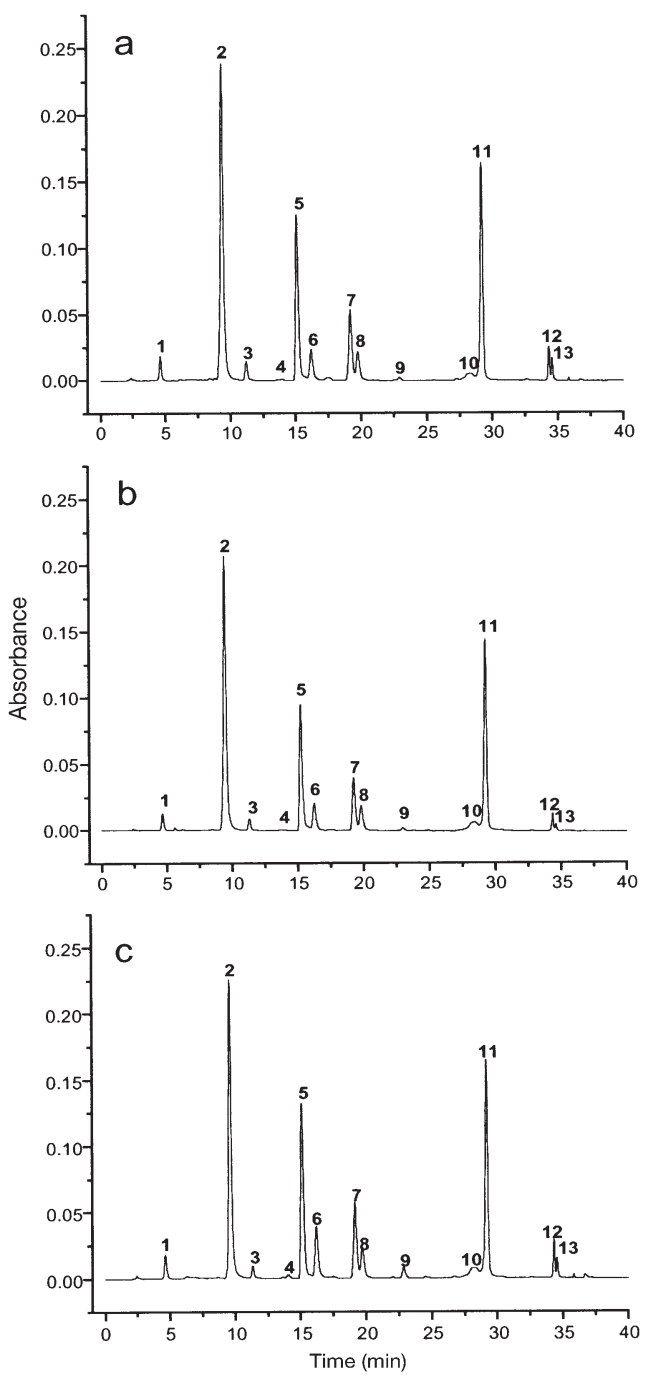

Fig. 4. HPLC chromatograms of pigment extracts (absorption at $436 \mathrm{~nm}$ ) from (a) Alexandrium catenella, (b) A. tamarense and (c) A. minutum. Peak identification: $1=$ peridininol, $2=$ peridinin, $3=\mathrm{MgDVP}, 4=\mathrm{Chl} c_{1}, 5=\mathrm{Chl} C_{2}, 6=$ dinoxanthin, 7 = diadinoxanthin, $8=$ diadinochrome, $9=$ diatoxanthin, $10=$ Chl $a$ allomer, $11=\mathrm{Chl} a, 12=\beta$-carotene, $13=$ pheophytin $a$

Table 3. Chlorophyll a content per cell and pigment ratios in Alexandrium species

\begin{tabular}{|lccc|}
\hline & A. catenella & A. tamarense & A. minutum \\
\hline Chl $\mathbf{a}\left(\right.$ pg cell $\left.^{-1}\right)$ & 21.2 & 16.5 & 11.3 \\
Pigment ratios $_{\text {[pg }}(\mathbf{p g ~ c h l ~} \mathbf{~ a})^{-1}$ ] & & \\
Chl $C_{2}$ & 0.35 & 0.29 & 0.38 \\
MgDVP & 0.04 & 0.04 & 0.03 \\
Peridinin & 1.33 & 1.22 & 1.13 \\
Peridininol & 0.07 & 0.05 & 0.07 \\
Diadinoxanthin & 0.17 & 0.14 & 0.18 \\
Diatoxanthin & Traces & Traces & 0.03 \\
Dinoxanthin & 0.07 & 0.07 & 0.12 \\
$\beta$-carotene & 0.04 & 0.02 & 0.04 \\
\hline
\end{tabular}

the products of its acid hydrolysis. These results are compatible with the polarity and spectral properties of M-320 and suggest that this compound is formed by condensation of shinorine with mycosporine-glycine, with the concomitant losses of a water molecule. The formation of an ester is compatible with the structure of these MAAs.

The spectrum of M-335/360 showed a peak at $335 \mathrm{~nm}$ and a pronounced inflection at $360 \mathrm{~nm}$ (Fig. 2). Controlled acid hydrolysis yielded shinorine, palythene and palythine in a molar ratio of 1.0:0.6:0.4. Shinorine and palythine are quite stable under acidic conditions, whereas palythene yielded palythine by treatment with dilute hydrochloric acid (Takano et al. 1978). Under our experimental conditions, the hydrolysis of palythene was partial (about $45 \%$ ) and yielded only palythine. These results suggest that M-335/360 contain shinorine and palythene in a 1:1 molar ratio. Moreover, the UV-visible absorption spectrum of this compound can be reconstructed from the molar spectra of these 2 MAAs. The negative-ion mass spectrum for the M-335/360 compound (Fig. 3a) showed a clear ion at $\mathrm{m} / \mathrm{z} 597.6$ that was assigned to the molecular ion. The identity of the ion was confirmed by the presence of a peak 23 mass units higher, attributed to the sodium adduct. As in the case of M-320, the molecular mass of this compound was 18 units lower than the calculated mass addition of their constitutive MAAs: shinorine (332.3) and palythene (284.1). These results together with the polarity, chemical and spectral properties of M-335/360 support the hypothesis that this compound is an ester formed by condensation of shinorine with palythene.

The absorption spectrum of M-328/360 showed a more complex shape (Fig. 2), with an extended plateau near the maximum absorption at $328 \mathrm{~nm}$ and an inflexion near $360 \mathrm{~nm}$. Controlled acid hydrolysis yielded shinorine, mycosporine-glycine and palythene as principal products. Their molar ratio was close to 1.0:1.0: 0.6 , respectively. Palythine and minor amounts of other unknown MAAs with maximum absorption at $320 \mathrm{~nm}$ were also detected as secondary products. These results suggest that $\mathrm{M}-328 / 360$ contains shinorine, mycosporine-glycine and palythene in 1.0:1.0:1.0 molar ratio. These MAAs are probably linked among themselves, although we do not have spectroscopic data available to confirm this hypothesis.

\section{Pigment composition}

The 3 species analysed here showed the same pigment pattern (Fig. 4, Table 3). They contained chlorophyll $a$, chlorophyll $c_{2}$, peridinin and diadinoxanthin as major pigments, and dinoxanthin, $\beta$-carotene, peri- 
dininol and diadinochrome as minor pigments. In the shade adapted cells, diatoxanthin was present in trace amounts; in accordance with the findings of Demers et al. (1991). This pigment composition supports other analyses of peridinin-containing dinoflagellates (Johansen et al. 1974, Jeffrey et al. 1975), although the peridinin related xanthophylls, pyrroxanthin and pyrroxanthinol (Johansen et al. 1974) were not detected in our Alexandrium isolates. In addition, the method here employed showed minor amounts of divinyl protochlorophyllide a (MgDVP) and trace amounts of chlorophyll $c_{1}$, which is in agreement with the results obtained by Zapata et al. (1998) for another strain (ALV1) of Alexandrium minutum. Only traces of pheophytin a were found. The 3 species showed similar pigment ratios (Table 3), although the proportion of photoprotective carotenoids (diadinoxanthin + diatoxanthin) to peridinin was slightly higher in A. minutum.

\section{Toxin composition}

Toxicity and toxin composition varied widely among the Alexandrium isolates analysed (Fig. 5, Table 4). The toxin contents of A. tamarense and A. catenella were similar (63.2 and $50.5 \mathrm{fmol} \mathrm{cell}^{-1}$ ) and several times higher than that of $A$. minutum $\left(1.0 \mathrm{fmol} \mathrm{cell}^{-1}\right)$. The low toxicity of this isolate (AL2V) of A. minutum (0.37 $\left.\mathrm{pgSTX}_{\mathrm{eq}} \mathrm{cell}^{-1}\right)$ is coincident with the results of Franco et al. (1994). Nevertheless, the toxin profile of the culture of AL2V analysed here, was more complex (Fig. 5) than that previously reported (Franco et al. 1994). In addition to the major toxins GTX4 (69.5\%) and GTX1 $(15.8 \%)$, small amounts of GTX2, GTX3, C1, C2, neoSTX and dcSTX were also observed. The toxin profile of $A$. tamarense and $A$. catenella, were very different from that of $A$. minutum. Both isolates (A. tamarense and A. catenella) contained sulfocarbamoyl derivatives in
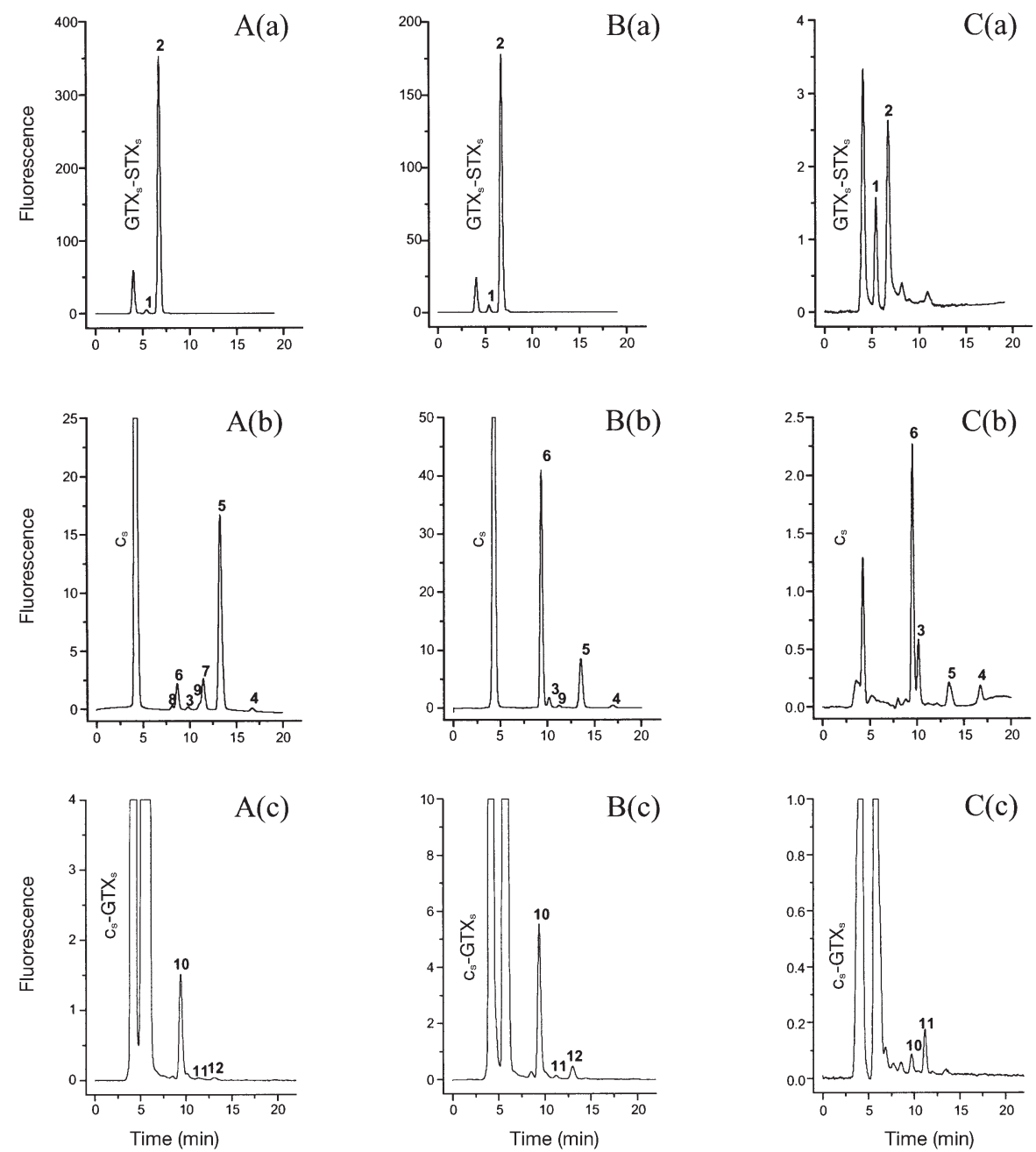

Fig. 5. HPLC chromatogram (fluorometric detection, $\lambda_{\text {ex }}: 330 \mathrm{~nm}, \lambda_{\text {em }}: 390 \mathrm{~nm}$ ) of (a) sulfocarbamoyltoxins, (b) gonyautoxins and (c) saxitoxins from: $\mathrm{A}=$ Alexandrium catenella, $\mathrm{B}=$ A. tamarense, $\mathrm{C}=\mathrm{A}$. minutum. Peak identification: $1=\mathrm{C} 1,2=\mathrm{C} 2,3=\mathrm{GTX} 1$, $4=$ GTX2, 5 = GTX3, 6 = GTX4, $7=$ GTX5, 8 = GTX6, $9=$ dcGTX3, $10=$ neoSTX, $11=$ dcSTX, $12=$ STX 
Table 4. Paralythic shellfish toxin content per cell and toxin percent ratios in Alexandrium species

\begin{tabular}{|c|c|c|c|c|c|c|}
\hline \multirow[b]{2}{*}{$\mathrm{C} 1$} & \multicolumn{2}{|c|}{$\begin{array}{r}\text { A. catenella } \\
\text { fmol cell }^{-1} \%\end{array}$} & \multicolumn{2}{|c|}{$\begin{array}{l}\text { A. tamarense } \\
\text { fmol cell }^{-1} \%\end{array}$} & \multicolumn{2}{|c|}{$\begin{array}{l}\text { A. minutum } \\
\mathrm{fmol} \mathrm{cell}^{-1} \%\end{array}$} \\
\hline & 0.78 & 1.5 & 1.65 & 2.7 & 0.02 & 1.9 \\
\hline $\mathrm{C} 2$ & 37.65 & 74.6 & 42.13 & 66.6 & 0.03 & 2.9 \\
\hline GTX1 & 0.17 & 0.3 & 0.67 & 1.1 & 0.17 & 15.8 \\
\hline GTX2 & 0.08 & 0.2 & 0.06 & 0.1 & 0.02 & 1.9 \\
\hline GTX3 & 3.94 & 7.8 & 0.88 & 1.4 & 0.03 & 2.8 \\
\hline GTX4 & 2.41 & 4.8 & 15.58 & 24.6 & 0.73 & 69.5 \\
\hline GTX5 & 4.03 & 8.0 & - & - & - & - \\
\hline GTX6 & 0.44 & 0.9 & - & - & - & - \\
\hline dcGTX3 & Traces & - & 0.03 & 0.1 & - & - \\
\hline neoSTX & 1.0 & 2.0 & 2.10 & 3.3 & 0.02 & 1.9 \\
\hline dcSTX & Traces & - & 0.03 & 0.1 & 0.04 & 3.4 \\
\hline STX & Traces & - & 0.11 & 0.2 & - & - \\
\hline Total & 50.50 & & 63.24 & & 1.049 & \\
\hline Toxicity $\left(\mathrm{pgSTX} \mathrm{eq}_{\mathrm{cell}}{ }^{-1}\right.$ ) & 4.65 & & 9.28 & & 0.37 & \\
\hline
\end{tabular}

large proportions (almost exclusively as the $\beta$ epimer). On the other hand, the relative abundance of other toxins was different in these 2 species. The most remarkable difference in the toxin profile of these isolates was the lack of GTX5 and GTX6 in A. tamarense.

\section{DISCUSSION}

The 3 species studied here showed noticeable differences in their toxin and MAA composition. In contrast, they had similar pigment pattern, characteristic of peridinin-containing dinoflagellates.

\section{Toxin composition}

Results found in the present study show large differences in the toxin profiles among isolates of Alexan- drium, which could be used to distinguish one species from another. A. minutum, the most divergent taxa relative to representatives of the Tamarense species complex (Scholin et al. 1994), also showed the most distinctive toxin profile. In addition, our results showed that the toxin profiles of $A$. minutum and $A$. tamarense were different from those previously obtained by Franco et al. (1994) and Montoya et al. (1998), for the same isolates (AL2V and MDQ1096, respectively). Toxin composition has long been recognised as a stable conservative property of a clone (Hall 1982, Oshima et al. 1990). On the other hand, recent studies have found considerable variation in toxin composition according to variations in growth conditions (Anderson et al. 1990, Taroncher-Odenburg et al. 1997). The predominant toxin composition of $A$. minutum has been reported to vary according to region and season, and also with environmental conditions and nutrient availability (Oshima et al. 1989, Franco et al. 1994, Alvito et al. 1995, Chang et al. 1997, Hwang et al. 1999,). Hence, the observed discrepancies are probably the result of differences in growth conditions.

\section{MAA distribution}

In contrast to the limited number of algal species reported to synthesise saxitoxins, many phytoplankton organisms from different regions and taxonomic groups have been found to contain MAAs (Jeffrey et al. 1999). However, the capacity to accumulate high amounts of these compounds, appears to be restricted

Table 5. Relative abundance of MAAs in some dinoflagellate species

\begin{tabular}{|c|c|c|c|c|c|c|c|}
\hline & $\begin{array}{l}\text { Alexandrium } \\
\text { tamarense }\end{array}$ & $\begin{array}{l}\text { Alexandrium } \\
\text { catenella }^{\mathrm{a}}\end{array}$ & $\begin{array}{l}\text { Alexandrium } \\
\text { minutum }^{\mathrm{a}}\end{array}$ & $\begin{array}{l}\text { Lingulodinium } \\
\text { polyedra }^{\mathrm{b}}\end{array}$ & $\begin{array}{l}\text { Gymnodinium } \\
\text { sanguineum }^{\mathrm{c}}\end{array}$ & $\begin{array}{l}\text { Prorocentrum } \\
\text { micans }^{\mathrm{d}}\end{array}$ & $\begin{array}{c}\text { Gymnodinium } \\
\text { catenatum }^{\mathrm{e}}\end{array}$ \\
\hline Shinorine & +++ & +++ & +++ & - & - & +++ & ++ \\
\hline Palythine & +++ & +++ & + & +++ & + & - & - \\
\hline Asterine & \pm & - & - & - & - & ++ & - \\
\hline Myc-methylamine-serin & ine + & + & + & - & - & - & - \\
\hline Porphyra-334 & +++ & ++ & +++ & ++++ & ++++ & - & +++ \\
\hline Palythinol & + & + & + & + & - & - & - \\
\hline Mycosporine-glycine & ++ & +++ & ++ & - & +++ & ++++ & +++ \\
\hline Myc-glycine-valine & - & - & - & + & - & - & - \\
\hline Palythenic acid & ++ & ++ & \pm & - & - & - & - \\
\hline M-320 & ++ & ++ & +++ & $++?$ & - & - & ++++ ? \\
\hline Usujirene & + & + & + & - & - & - & - \\
\hline Palythene & ++++ & ++++ & +++ & +++ & +++ & - & - \\
\hline New MAAs & + & + & ++++ & - & - & - & + \\
\hline
\end{tabular}


to surface bloom-forming dinoflagellates, cryptomonads and raphidophytes (Carreto et al. 1989, Sinha et al. 1998, Jeffrey et al. 1999).

Among dinoflagellates, only a few species are known to establish distribution patterns (Table 5). Dinoflagellates have a suite of common widespread MAAs, although it is evident that MAA composition is species dependent. Species of the genus Alexandrium have the most complex MAA profiles. To talk about the possibility of distinguishing species according to their MAA profiles, would only be valid if inter-specific variations are larger than intra-specific physiological variations. In dinoflagellates, the MAA composition is modified by a variety of environmental factors, such as light intensity (Carreto et al. 1989, Lesser et al. 1996, Neale et al. 1998), spectral light composition (Carreto et al. 1990b, Lesser et al. 1996), temperature, growth phase and probably to a small extent, time of sampling in the diurnal cycle (Carreto et al. unpubl. results). For example, in the dinoflagellate $A$. excavatum (= A. tamarense), the transfer from low $\left(20 \mu \mathrm{mol}\right.$ quanta $\mathrm{m}^{-2}$ $\left.\mathrm{s}^{-1} \mathrm{PAR}\right)$ to high (200 $\mu \mathrm{mol}$ quanta $\left.\mathrm{m}^{-2} \mathrm{~s}^{-1} \mathrm{PAR}\right)$ irradiance leads to a change in MAA composition and an overall increase in the cell content of MAAs in a time scale of a few hours (Carreto et al. 1989). Similar results have been reported for the dinoflagellate Gymnodinium sanguineum (Neale et al. 1998) and observed by ourselves in A. catenella (Carreto et al. 1999). A typical response observed for these species to increasing light conditions is a dramatic increase in the relative abundance of palythene (Carreto et al. 1990a, Neale et al. 1998). The methodology used is another complicating factor as the development of new analytical methods has allowed the detection of new or previously unresolved compounds. Among the studied dinoflagellates, usujirene has only been detected in the Alexandrium isolates. However, this is probably related to the methodology employed, which allows the separation of palythene from their isomer usujirene.

\section{Occurrence of novel MAAs}

Our study also documents that an important distinctive feature of Alexandrium species is the occurrence of novel MAAs, not previously reported in the literature. However, in cultures of Lingulodinium polyedra, Vernet \& Whitehead (1996) reported the presence of an unknown, low polarity MAA with absorption maximum at $320 \mathrm{~nm}$, that seems to be similar to our M-320 compound. Recently, Jeffrey et al. (1999) showed that the toxic dinoflagellate Gymnodinium catenatum, in addition to mycosporine-glycine, shinorine and porphyra-334 also contained major quantities of unknown UV-absorbing compounds. The most abundant of these compounds also showed a $320 \mathrm{~nm}$ absorption maximum, but differ from palythine in their polarity.

Spectrally similar compounds containing 2 chromophores with absorption maxima at 312 and $335 \mathrm{~nm}$ have been isolated in the terrestrial cyanobacterium Nostoc commune. These high molecular mass, water soluble compounds are the first MAAs to be described covalently linked to oligosaccharides (Böhm et al. 1995). Other spectrally similar MAAs have also been isolated from another strain of terrestrial cyanobacteria, but the chemical nature of these compounds is still unknown (Garcia-Pichel \& Castenholz 1993).

In our study, partial characterisation of 4 novel MAAs from Alexandrium species indicates the existence of 2 types of compounds closely related to known MAAs. One of them (M-333) appears to be a monomethyl ester of shinorine. The other type of compounds contain 2 (M-320: shinorine and mycosporine-glycine, M-335/360: shinorine and palythene) or 3 (M328/360: shinorine, mycosporine-glycine and palythene) MAAs covalently linked among themselves. We believe that they are esters, although we do not have NMR data available to confirm their structure.

The 3 Alexandrium species studied here, can synthesise these novel compounds. The chromatographic profile of A. minutum, however, was noticeably distinct from those of A. tamarense and A. catenella. Thus, A. minutum, the most divergent taxa relative to $A$. tamarense and A. catenella (Scholin et al. 1994), showed the most distinctive toxin composition and MAA profile. One explanation for this, is that variations in MAA composition between different isolates or species reflect genetic differences in their ability to synthesise MAAs. This explanation is still speculative, since their synthesis in Alexandrium and Gymnodinium catenatum (Jeffrey et al. 1999) has yet to be achieved. Another possible explanation for variations in MAA content and composition in different isolates or species of bloom-forming dinoflagellates, is the role that other organisms - most notably bacteria can play in MAA synthesis. It is feasible that endosymbiotic bacteria present in some of these organisms (Doucette 1995) are capable of the de novo synthesis of MAAs. Also they can be the provider of at least some of the intermediate metabolites, or may be responsible for interconversions of MAAs, such as the transformation of common MAAs to complex compounds. Dunlap \& Shick (1998), for instance, suggested that Vibrio harveyi can hydrolyse the hydroxyamino acid substituents of shinorine and porphyra-334, to yield mycosporine-glycine.

\section{Ecological considerations}

The experiments performed by Neale et al. (1998), provided optical evidence that MAAs act as spectrally 
specific UV sunscreens and are direct protectans in the red tide dinoflagellate Gymnodinium sanguineum, and possibly other MAA-accumulating phytoplankton with similar size as G. sanguineum. The advantage of the cumulative effect of having several MAAs with different absorption maxima between 310 and $360 \mathrm{~nm}$ is that the filtering capability is broadened. Thus, increased protection across a large range of deleterious UVA and UVB wavelengths is attained (Carreto et al. 1990a, Neale et al. 1998, Jeffrey et al. 1999). On this basis, the functionality of the novel compounds is not clear, since they absorb light in the same spectral range of their constitutive MAAs. However, there may be physiological limitations to the accumulation of osmotically active compounds such as common MAAs within the cells and probably the maximal specific content of MAAs in the cell is regulated by osmotic mechanisms (Oren 1998, Sinha et al. 1998). The reduction of the number of ionizable groups that accompany the synthesis of novel MAAs could be a mechanism to counteract these limitations and explain the high accumulation capacity observed in the studied Alexandrium species and probably in other surface bloom-forming dinoflagellates.

One of the most conspicuous characteristics that accompanies red tide development is high isolation and calm periods (Carreto et al. 1993). In these meteorological conditions, the increase of UV radiation in combination with others factors (nutrients and stability) may alter the phytoplanktonic community, thus favouring the development of the best adapted species. Moreover, UVB reaching the Earth's surface is increasing as a result of anthropogenic damage to the stratospheric ozone layer. Ozone depletion is expected to increase and spread to lower latitudes in the next century (Madronich et al. 1995). This could alter the floristic composition of temperate marine phytoplankton species to favour harmful surface bloom-forming species.

\section{CONCLUSION}

Our study documents for the first time the occurrence of novel complex MAAs in some species of bloom-forming dinoflagellates. The abundance and distribution of these novel compounds are species specific, suggesting some degree of biogeographical or ecotypical diversification. Alexandrium minutum, the most divergent taxa relative to representatives of the Tamarense complex, showed the most distinctive toxin and MAA profiles. However, the use of these compounds as biological markers should be taken with caution, as only a few species of the group have been analysed until now and the physiological regulation of their synthesis - including the role of bacteria - is still unknown to a great extent.
Acknowledgements. This work was partially supported by the Aquatoxsal Project of the European Union (DG XII, Program INCO-DC). We are grateful to Dr M. Seguel and Dr J. Franco for providing Alexandrium catenella and A. minutum strains, to Dr Y. Oshima for providing toxin standards, to Dr T. Teai for Pocillopora eydouxi MAA standards and to Dr Jorge Furlong (Agilent Technologies, Argentine) for mass spectrometry measurements. We thank Dr V. Lutz for reading the manuscript, Dr S. W. Jeffrey and 2 anonymous reviewers that provided helpful comments and suggestions on the manuscript. Contribution of INIDEP No. 1178

\section{LITERATURE CITED}

Alvito P, Sousa I, Franca S, Mascarenhas V (1995) Estudo experimental da relaçao entre salinidade e toxicidade em culturas de Alexandrium lusitanicum. In: Matamoros E, Delgado M (eds) IV Reunión ibérica sobre fitoplancton tóxico y biotoxinas. Generalitat de Catalunya, Barcelona, p 77-82

Anderson DM (1990) Toxin variability in Alexandrium species. In: Graneli E, Sundström B, Edler L, Anderson DM (eds) Toxic marine phytoplankton. Elsevier, New York, p 11-16

Arpin N, Bouillant ML (1981) Light and mycosporines. In: Turian G, Hohl HR (eds) The fungal spore, morphogenetic controls. Academic Press, London, p 159-173

Banaszak AT, Trench R (1995) Effects of ultraviolet (UV) radiation on marine microalgal-invertebrate symbioses. II. The synthesis of mycosporine-like amino acids in response to exposure to UV in Anthopleura elegantissima and Cassiopeia xamachana. J Exp Mar Biol Ecol 194:233-250

Bandaranayake WM (1998) Mycosporines: are they nature's sunscreens? Natural product reports. R Soc Chem Spec Publ 15:159-173

Boalch WM, Haxo FT (1984) Spectral properties of Noctiluca miliaris Suriray, a heterotrophic dinoflagellate. J Plankton Res 6:515-525

Böhm GA, Pfleiderer W, Böger P, Scherer S (1995) Structure of a novel oligosaccharide-mycosporine-amino acid ultraviolet $\mathrm{A} / \mathrm{B}$ sunscreen pigment from the terrestrial cyanobacterium Nostoc commune. J Biol Chem 270:9-17

Carreto JI, De Marco SG, Lutz VA (1989) UV-absorbing pigments in the dinoflagellates Alexandrium excavatum and Prorocentrum micans. Effects of light intensity. In: Okaichi T, Anderson DM, Nemoto T (eds) Red tides: Biology, environmental science and toxicology. Elsevier, New York, p 333-336

Carreto JI, Lutz VA, De Marco SG, Carignan MO (1990a) Fluence and wavelength dependence of mycosporine-like amino acid synthesis in the dinoflagellate Alexandrium excavatum. In: Graneli E, Sundström B, Elder L, Anderson DM (eds) Toxic marine phytoplankton. Elsevier, New York, p 275-279

Carreto JI, Carignan MO, Daleo G, De Marco SG (1990b) Occurrence of mycosporine-like amino acids in the redtide dinoflagellate Alexandrium excavatum: UV-photoprotective compounds? J Plankton Res 12:909-921

Carreto JI, Elbusto C, Sancho H, Carignan MO, Cucchi Colleoni D, De Marco S, Fernandez A (1993) An exploratory analysis of the Mar del Plata shellfish toxicity area (1980-1990). In: Smayda TJ, Shimizu Y (eds) Toxic phytoplankton blooms in the sea. Elsevier, Amsterdam, p 377-382

Carreto JI, Carignan MO, Montoya NG (1999) Effect of the solar radiation on the production of pigments and mycosporine-like amino acids. In: Arzul G (ed) Proceedings of 
the International Workshop on Preservation of Marine Environment in the South of Latin America, Aquaculture Extension and Phytoplankton Development. IFREMER, p 60-71

Chang FH, Anderson DM, Kulis DM, Till DG (1997) Toxin production of Alexandrium minutum (Dinophyceae) from the Bay of Plenty, New Zealand. Toxicon 35:393-409

Demers S, Roy S, Cagnon R, Vignault C (1991) Rapid lightinduced changes in the cell fluorescence and in xanthophyll-cycle pigments in Alexandrium excavatum (Dinophyceae) and Thalassiosira pseudonana (Bacillariophyceae): a photoprotection mechanism. Mar Ecol Prog Ser 76:185-193

Doucette GJ (1995) Assessment of the interaction of prokaryotic cells with harmful algal species. In: Lassus P, Arzul G, Erard E, Gentien P, Marcaillou C (eds) Harmful marine algal blooms technique \& documentation. Lavoisier Ltd, Paris , p 385-400

Dunlap WC, Yamamoto Y (1995) Small-molecule antioxidants in marine organisms: antioxidant activity of mycosporineglycine. Comp Biochem Physiol 112:105-114

Dunlap WC, Shick JM (1998) Ultraviolet ratiation-absorbing mycosporine-like amino acids in coral reef organisms: a biochemical and environmental perspective. J Phycol 34: 418-430

Einarsson S, Folestad S, Josefsson B, Lagerkvist S (1986) High-resolution reversed-phase liquid chromatography system for the analysis of complex solutions of primary and secondary amino acids. Anal Chem 58:1638-1643

Fabre-Bonvin J, Arpin N, Brevard C (1976) Structure de la mycosporine (P310). Can J Chem 54:1105-1113 (English Abstract)

Franco JM, Fernandez P, Reguera B (1994) Toxin profiles of natural populations and cultures of Alexandrium minutum Halim from Galician (Spain) coastal waters. J Appl Phycol 6:275-279

Garcia-Pichel F, Castenholz RW (1993) Occurrence of UVabsorbing mycosporine-like compounds among cyanobacterial isolates and an estimate of their screening capacity. Appl Environ Microbiol 59:163-169

Garrido JL, Zapata M (1997) Reversed-phase high performance liquid chromatographic separation of mono- and divinyl chlorophyll forms using pyridine-containing mobile phases and a polymeric octadecylsilica column. Chromatographia 44:43-49

Guillard RRL (1995) Cultured methods. In: Hallegaeff GM, Anderson DM, Cembella AD (eds) Manual on harmful marine microalgae. IOC Manuals and Guides No 33, UNESCO, Paris

Hall S (1982) Toxins and toxicity of Protogonyaulax from the northeast Pacific. PhD thesis, University of Alaska

Hwang DF, Tsai YH, Liao HJ, Matsuoka K, Noguchi T, Jeng SS (1999) Toxins of the dinoflagellate Alexandrium minutum Halim from the coastal waters and aquaculture ponds in southern Taiwan. Fish Sci 65:171-172

Jeffrey SW, Sielicki M, Haxo FT (1975) Chloroplast pigments patterns in dinoflagellates. J Phycol 11:374-384

Jeffrey SW, Mantoura RFC, Wright SW (1997) Phytoplankton pigments in oceanography: guidelines to modern methods. UNESCO publishing, Paris

Jeffrey SW, Mac Tavish HS, Dunlap WC, Vesk M, Groenewoud K (1999) Occurrence of UVA- and UVB-absorbing compounds in 152 species (206 strains) of marine microalgae. Mar Ecol Prog Ser 189:35-51

Johansen JE, Svec WA, Liaaen-Jensen S, Haxo FT (1974) Carotenoids of the Dinophyceae. Phytochemistry 13: 2261-2271
Johnsen G, Sakshaug E (1996) Light harvesting in bloomforming marine phytoplankton: species-specifity and photoacclimation. Sci Mar 60:47-56

Karentz D, Mc Euen FS, Land MC, Dunlap WC (1991) Survey of mycosporine-like amino acid compounds in Antarctic marine organisms: potential protection from ultraviolet exposure. Mar Biol 108:157-166

Lesser MP (1996) Acclimation of phytoplankton to UV-B radiation: oxidative stress and photoinhibition of photosynthesis are not prevented by UV-absorbing compounds in the dinoflagellate Prorocentrum micans. Mar Ecol Prog Ser 132:287-297

Madronich S, McKenzie RL, Björn LO, Caldwell MM (1995) Changes in biologically active ultraviolet radiation reaching the Earth's surface. J Photochem Photobiol B Biol 46:5-19

Montoya NG, Reyero MI, Akselman R, Franco JM, Carreto JI (1998) Paralytic shellfish toxins in the anchovy Engraulis anchoita from the Argentinian coast. In: Reguera B, Blanco J, Fernandez ML, Wyatt T (eds) Harmful algae. Xunta de Galicia and IOC-UNESCO, Santiago de Compostela, p 72-73

Neale PJ, Banaszak AT, Jarriel CR (1998) Ultraviolet sunscreens in Gymnodinium sanguineum (Dinophyceae): Mycosporine-like amino acids protect against inhibition of photosynthesis. J Phycol 34:928-938

Oren A (1997) Mycosporine-like amino acids as osmotic solutes in a community of halophilic cyanobacteria. Geomicrobiol J 14:231-240

Oshima Y, Sugino K, Itakura H, Hirota, M Yasumoto T (1990) Comparative studies on paralytic shellfish toxin profile of dinoflagellates and bivalves. In: Graneli E, Sundström B, Edler L, Anderson DM (eds) Toxic marine phytoplankton. Elsevier, New York, p 391-396

Oshima Y (1995) Post-column derivatization HPLC methods for paralytic shellfish poisons. In: Hallegraeff GM, Anderson DM, Cembella AD (eds) Manual on harmful marine microalgae. IOC-UNESCO, Paris, p 81-94

Oshima Y, Sugino K, Yasumoto T (1989) Latest advances in HPLC analysis of paralytic shellfish toxins. In: Natori $\mathrm{S}$, Hashimoto K, Ueno Y (eds) Mycotoxins and phycotoxins 1988. Elsevier, Amsterdam, p 319-326

Scholin C, Herzog M, Sogin ML, Anderson DM (1994) Identification of group and strain-specific genetic markers for globally distributed Alexandrium (Dinophyceae). Sequence analysis of a fragment of the LSU rRNA gene. J Phycol 30:999-1011

Sinha RP, Klisch M, Gröninger A, Häder DP (1998) Ultraviolet-absorbing/screening substances in cyanobacteria, phytoplankton and macroalgae. J Photochem Photobiol B Biol 47:83-94

Takano S, Uemura D, Hirata Y (1978) Isolation and structure of two new amino acids, palythinol and palythene, from the zoanthid Palythoa tuberculosa. Tetrahedron Lett 49: 4909-4912

Takano S, Nakanishi A, Uemura D, Hirata Y (1979) Isolation and structure of a $334 \mathrm{~nm}$ UV-absorving sustance, porphyra-334 from the red alga Porphyra tenera Kjellman. Chem Lett (Chem Soc Japan, Tokio) 419-420

Taroncher-Oldenburg G, Kulis DM, Anderson DM (1997) Toxin variability during the cell cycle of the dinoflagellate Alexandrium fundyense. Limnol Oceanogr 42:1178-1188

Vernet M, Whitehead K (1996) Release of ultraviolet-absorbing compounds by the red-tide dinoflagellate Lingulodinium polyedra. Mar Biol 127:35-44

Vernet M, Neori A, Haxo FT (1989) Spectral properties and photosynthetic action in red-tide populations of Prorocen- 
trum micans and Gonyaulax polyedra. Mar Biol 103:365-371 Yentsch CS, Yentsch CM (1982) The attenuation of light by marine phytoplankton with specific reference to the absorption of near-UV radiation. In: Calkins J (ed) The role of solar ultraviolet radiation in marine ecosystems. Plenum, New York, p 691-700

Editorial responsibility: Otto Kinne (Editor), Oldendorf/Luhe, Germany
Zapata M, Freire J, Garrido JL (1998) Pigment composition of several harmful algae as determined by HPLC using pyridine-containing mobile phases and a polymeric octadecylsilica column. In: Reguera B, Blanco J, Fernandez ML, Wyatt T (eds) Harmful algae. Xunta de Galicia and IOCUNESCO, Santiago de Compostela, p 304-307

Submitted: April 17, 2000; Accepted: April 26, 2001 Proofs received from author(s): November 19, 2001 